\title{
OPTIMISATION OF ACID HYDROLYSIS IN ETHANOL PRODUCTION FROM AMPELODESMOS MAURITANICUS (DISS)
}

\author{
Chenah May, Amrani Moussa \\ M'hamed Bougara University \\ Boumerdes, Algeria \\ (Received February 2020)
}

\begin{abstract}
In this work, statistical modeling and optimization of hydrolyzate from Ampelodesmos mauritanicus (Diss) using 1.5\% sulfuric acid hydrolysis was carried. A central composite design $(\mathrm{CCD})$ model was used to study the influence of reaction temperature $\left(70^{\circ} \mathrm{C}\right.$ to $\left.110^{\circ} \mathrm{C}\right)$, ratio $(5 \%$ to $15 \%, \mathrm{w} / \mathrm{v})$, and reaction time (60 to $180 \mathrm{~min})$. Reducing sugars, $\mathrm{pH}$, proteins, lignin, ash content and the elements minerals composition were determined. Optimized reducing sugars yield of $0.249 \mathrm{gg}^{-1}$ of dry weight was obtained for reaction time of $180 \mathrm{~min}$, reaction temperature of $110^{\circ} \mathrm{C}$ and ratio $5 \%(\mathrm{w} / \mathrm{v})$. Therefore, this study tests the production of bioethanol from pure Diss hydrolyzate by the yeast Saccharomyces cerevisiae ATCC 9763. This strain showed a consumption of $67.6 \%$ of reducing sugars available $\left(25 \mathrm{~g} \cdot \mathrm{L}^{-1}\right)$, which made it possible to obtain ethanol yield per consumed sugar $0.33 \mathrm{~g} \cdot \mathrm{g}^{-1}$.
\end{abstract}

KEYWORDS: Biomass, hydrolyzate, optimization, bioethanol, Ampelodesmos mauritanicus (Diss).

\section{INTRODUCTION}

First generation biofuels or agro-fuels are obtained from oilseeds, sugar crops, and cereals; their production requires the use of large agricultural areas and water. As a result, first-generation biofuels compete directly with the food chain and can contribute to the food crisis (Demirbas 2007). Second-generation biofuels are produced from non-edible plant biomass, that is to say a dissociation of food and energy crops (Pažitný et al. 2013). Moreover, agronomic residues such as corn stover (corn cobs and stalks), sugar cane waste, wheat or rice straw, forestry and paper mill discards, the paper portion of municipal waste, and mainly dedicated energy crops collectively termed 'biomass' can be converted to fuel ethanol (Pažitný et al. 2019a,b). Algeria, as many Mediterranean countries, has large extreme environment areas that are unsuitable for agriculture 
as stony and/or semiarid environments. The lignocellulosic biomass Ampelodesmos mauritanicus, called Diss, grown in these areas, is a high perennial herbaceous plant, blooms between April and June. The leaves are long-lasting up to 1 meter and $7 \mathrm{~mm}$ wide, extremely rough could represent great potential as biorefinery (Boutine 2011). The structure of the Ampelodesmos mauritanicus mainly consists in lignin, cellulose, and hemicellulose arranged in cell walls, forming a complex network in which lignin builds a physical protection around the sugar fraction. Cellulose and hemicelluloses content is more than 60\% (Chenah and Amrani 2018). Therefore, hydrolyzate of Ampelodesmos mauritanicus mainly content glucose, xylose, and arabinose. The bioconversion lignocellulosic biomass involves three important stages that ultimately lead to production of bioethanol. The stages include pretreatment, hydrolysis of holocellulose to fermentable sugars and fermentation of sugars to yield the bioethanol. Hydrolysis represents the crucial stage for the performance of the whole process (Vargas et al. 2005). Various hydrolysis methods are widely studied, including physical, chemical and biological pathways, or a combination of two or more of them to produce an effective hydrolyzate (Singh et al. 2014, Carvalho et al. 2016, Gigac et al. 2017, Stankovská et al. 2018). Therefore, the goal of this work was to set up an experimental design that optimizes the operational conditions of a multivariate system (Montgomery 2001, Khajvand et al. 2011) and the interaction between the variables would also be taken into account to produce a hydrolyzate rich in reducing sugars from the stems of the Diss by dilute acid hydrolysis. The number of experimental trials would be reduced by the statistical design of the experiments (Lu et al. 2009). We have chosen the Response Surface Methodology (RSM) because it has important applications in the design, analysis and optimization of existing products and unit operations, its use thus decreasing the volume of experiments, reagents, time, financial contributions, and energy among others (Montgomery 2009).

In this study, a central composite design (CCD) model was used to study the influence of three parameters namely the ratio (solid/solvent), the extraction temperature and the extraction time, on the yield of the reducing sugars (RS) in the Diss hydrolyzate. The hydrolysis was carried out by dilute sulfuric acid of concentration at $1.5 \%$. The next step was to test the optimized hydrolyzate as a fermentative culture medium to produce bioethanol by Saccharomyces cerevisiae ATCC 9763.

\section{MATERIAL AND METHODS}

\section{Materials}

Ampelodesmos mauritanicus (Diss) was collected from the north east of Boumerdès area, Algeria. Biomass material was harvested in early June 2016. The sample was washed with water to remove dirt, dried at $60^{\circ} \mathrm{C}$ for $8 \mathrm{~h}$ in an air oven and reduced to about $2 \mathrm{~cm}$ in length, with a razor blade, for effective milling to a size less than $500 \mu \mathrm{m}$.

Saccharomyces cerevisiae ATCC 9763 was supplied by the pharmaceutical industry Saidal Alger (Algeria). The strain was subcultured sterilely on slant agar and in Petri dishes and stored at $4^{\circ} \mathrm{C}$.

\section{Acid hydrolysis}

The stems of the Diss were previously washed and crushed $(0.5-1 \mathrm{~mm})$ to obtain a homogeneous powder. The extraction was carried out using sulfuric acid of low concentration fixed at $1.5 \%$. The mixture was then treated in an autoclave at temperature of $70-110^{\circ} \mathrm{C}$ and at a ratio of $5-15 \%(\mathrm{w} / \mathrm{v})$ for time of $60-180 \mathrm{~min}$. After cooling, the autoclaved liquid hydrolyzate was separated by centrifugation and vacuum filtration. 


\section{Detoxification of hydrolyzate}

The original hydrolyzate was heated to $50-52^{\circ} \mathrm{C}$ by addition of calcium hydroxide to increase the $\mathrm{pH}$ to 10.0 , and thereafter the mixture was maintained at $50-52^{\circ} \mathrm{C}$ and stirred for $30 \mathrm{~min}$ using the heater stir plate, followed by filtration on Whatman filter paper, and the filtrate was allowed to cool to $30^{\circ} \mathrm{C}$. The filtrate was then re-acidified to $\mathrm{pH} 5.5$ with sulfuric acid, followed by Whatman filter paper filtration to remove any precipitate formed. And then the filtrate was aerated to remove the volatiles by sparging with nitrogen for 4 hours. To remove any condensed lignin residue, activated carbon was added in ratio (W/V) $1 \%$, stirred for $15 \mathrm{~min}$, thereafter filtration, to remove traces of activated carbon, this detoxified liquid hydrolyzate was then ready for use as a fermentation substrate and then stored at $4^{\circ} \mathrm{C}$ prior to use.

\section{Experimental plan and statistical analysis}

Central Composite Design, which allows to optimize three extraction parameters was chosen to use. CCD consists of three parts: a central point, a complete factorial model with points at the corners of a cube, and a star pattern with points located at a distance from the center. Whereas the distance at the center of the factorial points is conventionally estimated at \pm 1 , the length of $\alpha$ depends on the number of variables taken into account by the model. In our study, we studied three factors, so that the value adopted for $\alpha$ was \pm 1.68 (Bezerra et al. 2008). The input factors chosen were the ratio $\left(X_{1}\right)$, the temperature $\left(X_{2}\right)$ and the hydrolysis time $\left(X_{3}\right)$ (Tab. 1). In total, 17 randomized experiments were performed, including three replicates at the center, to estimate the sum of the pure square error (Tab. 2). Finally, in order to evaluate the effect of the variables on the response, a regression analysis and an ANOVA analysis were performed using STATISTICA software (V10), based on a complete quadratic polynomial model with a $95 \%$ confidence level (probability $\mathrm{p} \leq 0.05$ ) to evaluate the significance of the variables of the response (\% RS), based on possible linear, quadratic, and cubic models:

$$
\mathrm{Y}=\beta_{0}+\sum \beta_{\mathrm{i}} \mathrm{X}_{\mathrm{i}}+\sum \beta_{\mathrm{ii}} \mathrm{X}_{\mathrm{i}}^{2}+\sum \sum \beta_{\mathrm{ij}} \mathrm{X}_{\mathrm{i}} \mathrm{X}_{\mathrm{j}}
$$

where: $\quad \mathrm{Y}$ - the predicted response (\% RS),

$\beta_{\mathrm{o}}, \beta_{\mathrm{i}}, \beta_{\mathrm{ii}}$ and $\beta_{\mathrm{ij}}$ - intercept, linear, quadratic and cross product regression terms,

$X_{i}, X_{j}$ - coded independent variables, linearly related to $X_{1}, X_{2}$, and $X_{3}$.

The actual factor level corresponding to the coded factor levels are shown in Tab. 1. Threedimensional surface plots were established based on the final equation determined for each response to demonstrate the effects of independent variables on the response.

Tab. 1: Uncoded and coded independent variables used in RSM design for hydrolyzate optimization.

\begin{tabular}{|l|c|c|c|c|c|}
\hline \multirow{2}{*}{ Independent variables } & \multicolumn{5}{|c|}{ Coded levels } \\
\cline { 2 - 6 } & $-\mathrm{a}$ & -1 & 0 & +1 & $+\mathrm{a}$ \\
\hline Ratio \% (w/v) & -1.68 & 5 & 10 & 15 & +1.68 \\
\hline Temperature $\left({ }^{\circ} \mathbf{C}\right)$ & -1.68 & 70 & 90 & 110 & +1.68 \\
\hline Hydrolysis time (h) & -1.68 & 1 & 2 & 3 & +1.68 \\
\hline
\end{tabular}

Strain cultivation and fermentation process

S. cerevisiae ATCC 9763 was grown in the medium containing $10 \mathrm{~g} \cdot \mathrm{L}^{-1}$ yeast extract, $10 \mathrm{~g} \cdot \mathrm{L}^{-1}$ peptone, and $1 \mathrm{~g} \cdot \mathrm{L}^{-1}$ glucose. The medium was first incubated at $30^{\circ} \mathrm{C}$ and $150 \mathrm{rpm}$ for $24 \mathrm{~h}$ as a preculturing step. Seed inoculums (50\%) were then added to the detoxified liquid 
hydrolyzate obtained previously. Cultures were maintained at $30^{\circ} \mathrm{C}$ and $150 \mathrm{rpm}$ in $250 \mathrm{~mL}$ conical flasks and these media used for propagation and acclimation of the seed cultures, once the absorbance of the culture at $610 \mathrm{~nm}$ was at 01 absorbance unit the suspension was centrifuged. The pellet was then recovered, dried and used to seed the fermentations. The fermentation test was repeated 3 times, in Erlenmeyer flasks containing $100 \mathrm{ml}$ of optimized and sterilized Diss hydrolyzate. The medium was inoculated with $1 \mathrm{~g} \cdot \mathrm{L}^{-1}$ of the yeast and subsequently incubated in an incubator New Brunswick Scientific for $72 \mathrm{~h}$ under anaerobic conditions ( $\mathrm{pH}$ 5.5, temperature $30^{\circ} \mathrm{C}$ and mixing rate $150 \mathrm{rpm}$ ).

\section{Characterization of detoxified hydrolyzate}

The reducing sugars were determined by 3,5-dinitrosalicylic acid (DNS) (Miller et al. 1959) the mineral elements were determined by X-ray fluorescence (XRF) on the PHILIPS PW 1480 spectrometer with a dispersive technical wavelength. Total protein was determined using a Kjeldahl method (Kirk 1950) and the lignin content was determined by according to the official method TAPPI T222 om-11.

\section{Dry cell weight and reducing sugars determinations}

The $100 \mathrm{ml}$ sample of each Erlenmeyer flasks of incubator was collected from every $6 \mathrm{~h}$ for $72 \mathrm{~h}$, out of which, $1 \mathrm{ml}$ was used for the analysis of biomass. The remaining was centrifuged at $8500 \mathrm{tr} \cdot \mathrm{min}^{-1}$ for $10 \mathrm{~min}$. The supernatant was stored in $1 \mathrm{ml}$ aliquots at $20^{\circ} \mathrm{C}$ until further analysis of residual reducing sugars and ethanol. Cell biomass concentration of pure culture batch fermentations was determined from a correlation between $\mathrm{OD}_{600}$ and cell dry weight using a spectrophotometer (OPTIZEN). The residual reducing sugars was quantified using the DNS method and ethanol concentration was determined based on the density of the alcohol distillate at $20^{\circ} \mathrm{C}$ and expressed in weight $\%(w / w)$. At least three measurements were made for each condition and the data given were averages.

\section{RESULTS AND DISCUSSION}

\section{RSM model development}

Instead of optimizing medium composition by a one factor at a time approach, the statistical RSM design provides the opportunity to determine the optimal conditions in any given parameters by establishing the relationship between factors and predicted responses. The RSM design was applied to obtain the precise factor values which results in the reducing sugars. The results are summarized in Tab. 2. The highest amount of reducing sugars extraction $\left(0.2489 \mathrm{~g} \cdot \mathrm{g}^{-1}\right.$ dry weight) was observed when the treatment was performed with ratio $5 \%(\mathrm{w} / \mathrm{v})$ at $110^{\circ} \mathrm{C}$ for $180 \mathrm{~min}$. In this context, it can be observed that the hydrolysis of cellulose with dilute acid usually requires high temperature and high hydrolysis time. In addition, we can observe in Tab. 2 the lowest yield reducing sugars $\left(0.0257 \mathrm{~g} \cdot \mathrm{g}^{-1}\right.$ dry weight $)$ was observed when hydrolysis was performed in the minimum values of temperature $70^{\circ} \mathrm{C}$, minimum hydrolysis time $60 \mathrm{~min}$ and maximum ratio concentration $15 \%(\mathrm{w} / \mathrm{v})$, respectively. The reducing sugars yield ranged from 0.2489 to $0.025 \mathrm{~g} \cdot \mathrm{g}^{-1}$ of dry weight. 
Vol. 65 (6): 2020

Tab. 2: Design matrix for the three factors and their experimental results.

\begin{tabular}{|c|c|c|c|c|c|c|}
\hline Run order & $\begin{array}{c}\text { Ratio }(\%) \\
\left(\mathrm{X}_{1}\right)\end{array}$ & $\begin{array}{c}\text { Temperature } \\
\left({ }^{\circ} \mathrm{C}\right) \\
\left(\mathrm{X}_{2}\right)\end{array}$ & $\begin{array}{c}\text { Residence } \\
\text { time } \\
(\mathrm{h})\left(\mathrm{X}_{3}\right)\end{array}$ & \multicolumn{2}{|c|}{$\begin{array}{c}\text { Reducing sugars yield (glucose } \\
\text { equivalent) g.g-1 of dry weight }\end{array}$} & $\begin{array}{c}\text { Residual } \\
(\mathrm{c})\end{array}$ \\
\cline { 1 - 3 } & 10 & 90 & 2 & 0.10816111 & 0.10324287 & 0.00491824 \\
\hline 1 & 10 & 90 & 3.68 & 0.19381611 & 0.18661763 & 0.00719848 \\
\hline 3 & 10 & 90 & 2 & 0.09886086 & 0.10324287 & -0.004382 \\
\hline 4 & 10 & 56.36 & 2 & 0.09129374 & 0.06247002 & 0.02882372 \\
\hline 5 & 5 & 110 & 1 & 0.13995118 & 0.13629377 & 0.00365741 \\
\hline 6 & 15 & 70 & 3 & 0.05457011 & 0.06904706 & -0.0144769 \\
\hline 7 & 5 & 70 & 3 & 0.11391376 & 0.12768062 & -0.0137669 \\
\hline 8 & 1.59 & 90 & 2 & 0.13202942 & 0.1203368 & 0.01169261 \\
\hline 9 & 5 & 110 & 3 & 0.24898291 & 0.24905438 & 0.000071466 \\
\hline 10 & 10 & 90 & 2 & 0.10008137 & 0.10324287 & -0.0031615 \\
\hline 11 & 15 & 110 & 3 & 0.19419582 & 0.18675931 & 0.00743651 \\
\hline 12 & 15 & 110 & 1 & 0.12205045 & 0.11910312 & 0.00294732 \\
\hline 13 & 10 & 123.63 & 2 & 0.22050448 & 0.23402706 & -0.0135226 \\
\hline 14 & 18.4 & 90 & 2 & 0.06018502 & 0.0565765 & 0.00360852 \\
\hline 15 & 15 & 70 & 1 & 0.02571196 & 0.03646003 & -0.0107481 \\
\hline 16 & 10 & 90 & 0.31 & 0.07249797 & 0.06439532 & 0.00810265 \\
\hline 17 & 5 & 70 & 1 & 0.03173312 & 0.04998916 & -0.018256 \\
\hline
\end{tabular}

(a) Experimental values, (b) theoretical values, (c) residues.

\section{Analysis of variance for the response surface model}

The results of analysis of variance (ANOVA) for the response surface model are shown in Tab. 3. Using the analysis of variance (ANOVA), significant effects $(\mathrm{p} \leq 0.05)$ of ratio temperature and residence time were observed. The Tab. 3 shows that the three linear factors $X_{1}, X_{2}$ and $X_{3}$ and quadratic $\mathrm{X}_{2}^{2}$ have a significant impact on the amount of reducing sugars in hydrolyzate. The regression coefficients were estimated and the following second order polynomial equation was obtained for optimum reducing sugars production (Tab. 4):

$$
Y=0.103243-0.018956 X_{1}+0.051004 X_{2}+0.036337 X_{3}+0.015912 X_{2}^{2}
$$

The optimal conditions to obtain the maximal extraction yield sugars were ratio $5 \%(\mathrm{w} / \mathrm{v})$, temperature $110^{\circ} \mathrm{C}$, and residence time $3 \mathrm{~h}$. The predicted value of reducing sugars yield was $0.249 \mathrm{~g}^{-1} \mathrm{~g}^{-1}$ of dry weight.

The results of this study show that the coefficient of determination $\mathrm{R}^{2}=0.966186$ for the regressed model predicting the extraction yield indicating that $96.61 \%$ of the variability of the response to the reducing sugars concentration could be explained by the model Eq. 2. A high $\mathrm{R}^{2}$ indicates that the variation could be satisfactorily accounted for in the data for model fit. The predicted model appeared to reasonably represent the observed values. Thus, the answer was sufficiently explained by the model. The $\mathrm{R}^{2}$ is not considered as the main point to imply the accuracy of the model, because in addition to the variable, the model will increase the value of $\mathrm{R}^{2}$. As a result, adj- $\mathrm{R}^{2}$ is more appropriate for evaluating the model if its value is greater than $90 \%$ (Tan et al. 2012). If many insignificant terms had been included in the model, the adjusted R2 


\section{WOOD RESEARCH}

would be remarkably lower than the $\mathrm{R}^{2}$ (Chan et al. 2009). In our study, the adjusted $\mathrm{R}^{2}$ was close to the corresponding $\mathrm{R}^{2}$ value (0.92). This value indicates a high degree of correlation between observed and predicted data (Fig. 1).

Tab. 3: Analysis of variance (ANOVA) of reducing sugars extraction efficiency.

\begin{tabular}{|c|c|c|c|c|c|}
\hline Factor & $\begin{array}{c}\text { Sum of } \\
\text { Squares (SS) }\end{array}$ & $\begin{array}{c}\text { Degrees of } \\
\text { freedom }\end{array}$ & $\begin{array}{l}\text { Mean } \\
\text { Square }\end{array}$ & F & Pvalue \\
\hline (1) ratio $(\mathrm{L})$ & 0.004907 & 1 & 0.004907 & 15.2028 & 0.005906 \\
\hline ratio $(Q)$ & 0.000308 & 1 & 0.000308 & 0.9545 & 0.361134 \\
\hline (2) temperature $(\mathrm{L})$ & 0.035527 & 1 & 0.035527 & 110.0626 & 0.000016 \\
\hline temperature $(\mathrm{Q})$ & 0.002854 & 1 & 0.002854 & 8.8425 & 0.020701 \\
\hline (3) time $(\mathrm{L})$ & 0.018032 & 1 & 0.018032 & 55.8629 & 0.000140 \\
\hline time (Q) & 0.000698 & 1 & 0.000698 & 2.1639 & 0.184757 \\
\hline $1 \mathrm{~L}$ by $2 \mathrm{~L}$ & 0.000007 & 1 & 0.000007 & 0.0208 & 0.889477 \\
\hline 1L by $3 \mathrm{~L}$ & 0.001017 & 1 & 0.001017 & 3.1513 & 0.119131 \\
\hline $2 \mathrm{~L}$ by $3 \mathrm{~L}$ & 0.000615 & 1 & 0.000615 & 1.9050 & 0.209985 \\
\hline Error & 0.002260 & 7 & 0.000323 & & \\
\hline Total SS & 0.066822 & 16 & & & \\
\hline
\end{tabular}

Tab. 4: Regression equation coefficients for sugars yield.

\begin{tabular}{|l|c|c|c|c|}
\hline \multicolumn{1}{|c|}{ Factors } & Coefficient & Standard error & $\mathbf{T}$ & $\mathbf{P}$ \\
\hline Mean/Interc. & 0.103243 & 0.010353 & 9.97263 & 0.000022 \\
\hline (1) ratio $(\mathrm{L})$ & -0.018956 & 0.004862 & -3.89908 & 0.005906 \\
\hline ratio $(\mathrm{Q}$ & -0.005228 & 0.005351 & -0.97696 & 0.361134 \\
\hline (2) temperature (L) & 0.051004 & 0.004862 & 10.49107 & 0.000016 \\
\hline temperature (Q) & 0.015912 & 0.005351 & 2.97364 & 0.020701 \\
\hline (3) time (L) & 0.036337 & 0.004862 & 7.47415 & 0.000140 \\
\hline time $(\mathrm{Q}$ & 0.007871 & 0.005351 & 1.47101 & 0.184757 \\
\hline 1L by 2L & -0.000915 & 0.006352 & -0.14411 & 0.889477 \\
\hline 1L by 3L & -0.011276 & 0.006352 & -1.77518 & 0.119131 \\
\hline 2L by 3L & 0.008767 & 0.006352 & 1.38022 & 0.209985 \\
\hline
\end{tabular}

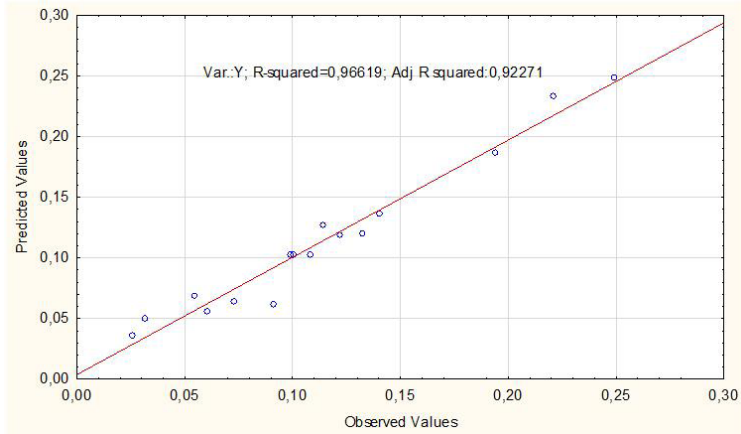

Fig. 1: Parity plot showing observed versus predicted values for the model. 


\section{Analysis of the response surface}

A response surface can be used to explain how two process parameters were interacted with each other when the third process parameter was fixed at a given. The response surface can also be used to determine the optimum levels of process parameters for the maximum response of RS yield at the highest point of the surface. The surface obtained from the reduced model is represented in Fig. 2.

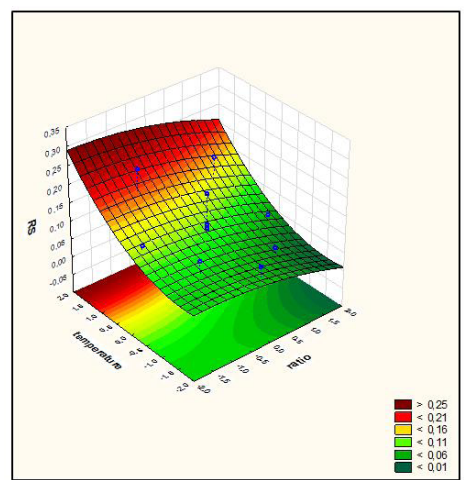

(a)

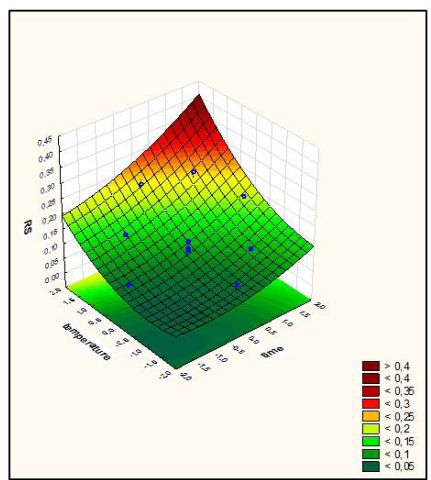

(b)

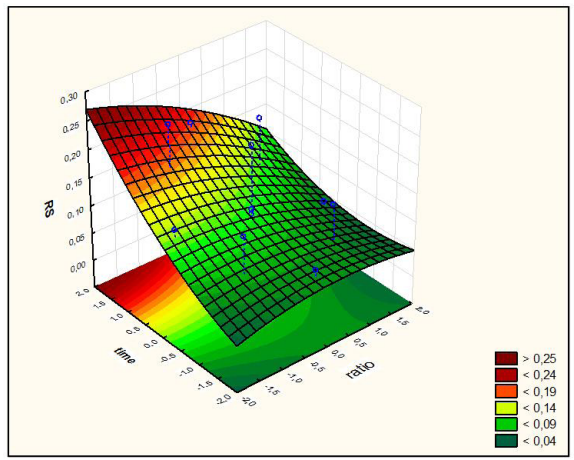

(c)

Fig. 2: Response surface reflecting the impact of interactions between ratioltemperature (a), temperaturel time (b), and between time/ratio (c).

It can be observed that RS ( $\mathrm{g} \cdot \mathrm{g}^{-1}$ of dry weight) varies positively and linearly with hydrolysis time and temperature, however negatively and linearly with ratio. In the presence of the lowest ratio (5\%), we obtained the highest yield (0.2489 $\mathrm{g}^{-1}$ dry weight). This yield decreases to a minimum value of $0.1941 \mathrm{gg}^{-1}$ in a ratio of $15 \%$, at the same temperature of $110^{\circ} \mathrm{C}$ and at the same hydrolysis time $3 \mathrm{~h}$ (Fig. 2a). According to the mathematical model, in its linear $\left(\mathrm{X}_{1}\right.$ and $\left.\mathrm{X}_{2}\right)$ and quadratic $\left(\mathrm{X}_{2}^{2}\right)$ form, the ratio and the temperature have a significant impact on the equivalent of glucose in the hydrolyzate, with the probabilities $0.005906,0.00016$ and 0.020701 successively (Tab. 3). Chambers et al. (1996) studied the kinetics during the extraction of a solute from oranges; they highlighted the influence of the temperature on the speed of extraction, its increase facilitating the diffusion. The temperature also favors cell division and makes it possible to recover a more concentrated juice (Wongkittipong et al. 2004). 
Fig. $2 \mathrm{~b}$ shows the influence of hydrolysis time $\left(\mathrm{X}_{3}\right)$ on the efficiency of RS extraction. It is found that in the presence of the lowest ratio (corresponding to -1 in coded value and $5 \%$ in real value) and the shortest time (1 h), we obtain a yield of $13.99 \%$. This yield increases until reaching a maximum concentration of $24.89 \%$ for an extraction time of 3 hours. Indeed, prolonged contact $\left(\mathrm{X}_{1}\right)$ of the plant material with the solvent, would allow greater extraction of reducing sugars.

Fig. 2c shows the influence of the ratio and the time on the extraction efficiency, where it is observed that the response (yield) is optimal when the ratio is low and the extraction time is at maximum, these results confirm those found previously.

\section{Characterization of Diss hydrolyzate}

The characterization results of the hydrolyzate are given in Tab. 5. The hydrolyzate of $\mathrm{pH}$ 5.5 contained $2.5 \%$ reducing sugars (RS), $0.14 \%$ proteins, $9.5 \%$ ash, and $0 \%$ lignin.

Tab. 5: Compounds and element minerals composition of hydrolyzate of Diss.

\begin{tabular}{|l|l|l|l|}
\hline \multicolumn{1}{|c|}{ Compounds } & \multicolumn{1}{c|}{ Rate (\%) } & \multicolumn{1}{c|}{ Compounds } & \multicolumn{1}{c|}{ Rate (\%) } \\
\hline $\mathrm{pH}$ & 5.5 & $\mathrm{Si}$ & 1.59 \\
\hline $\mathrm{RS}$ & 2.5 & & \\
\hline Proteins & 0.14 & $\mathrm{Al}$ & 0.617 \\
\hline Ashes & 9.5 & $\mathrm{Fe}$ & 0.148 \\
\hline Lignin & 0 & $\mathrm{Ca}$ & 24.2 \\
\hline & & $\mathrm{Mg}$ & 4.05 \\
\hline & & $\mathrm{Na}$ & 1.75 \\
\hline & & $\mathrm{K}$ & 5.91 \\
\hline & & $\mathrm{Zn}$ & 0.0374 \\
\hline & & $\mathrm{Mn}$ & 0.0601 \\
\hline & & $\mathrm{P}$ & 0.0651 \\
\hline & & $\mathrm{Sr}$ & 0.0237 \\
\hline & & $\mathrm{Cl}$ & 9.7 \\
\hline
\end{tabular}

Reducing sugars expressed in glucose equivalent will be used as a substrate during fermentation. Glucose is the most preferred carbon source for S. cerevisiae (Busti et al. 2010) and can be fermented faster than any other sugar. To date, no other carbon source has been consumed faster and more efficiently than glucose in wild or modified $S$. cerevisiae. The level of RS in the hydrolyzate is satisfactory to allow alcoholic fermentation and is far from being a fermentation inhibitor since the inhibition by the substrate is significant for glucose concentrations of $150250 \mathrm{~g} \cdot \mathrm{L}^{-1}$ and at $400 \mathrm{~g} \cdot \mathrm{L}^{-1}$, growth is completely stopped (Wang et al. 1979). The $\mathrm{pH}$ of the optimized hydrolyzate is satisfactory, the $\mathrm{pH}$ limits reported in the literature to maintain the growth of the yeast Saccharomyces cerevisiae are between 2.4 and 8.6, with an optimum $\mathrm{pH}$ of between 4 and 4.5 (Jones et al. 1981). Maintaining cytoplasmic $\mathrm{pH}$ is essential for yeast survival. Nitrogen is an essential element and must therefore be present in the culture medium to be assimilated (Thomas and Inglewed 1992). Yeasts can use different sources of nitrogen such as amino acids, peptides, simple bases (choline, betaine), but nitrogen in the form of ammonium ion is more easily assimilated (Winter et al. 1989). With respect to lignin, the results show that it has been completely eliminated and that the detoxification treatment used in this study was effective because the activated carbon has a high adsorption capacity of lignin (Silva et al. 1998, Mussatto and Roberto 2001). According to the Tab. 5, the hydrolyzate of Diss is rich in trace 
elements, necessary for the growth of yeast and therefore for the production of ethanol. Its $\mathrm{K}+$ content contributes to the regulation of the intercellular $\mathrm{pH}$, its $\mathrm{Ca}+$ content to be incorporated in the membrane proteins and to the protection of the yeast against the osmotic pressure caused by the sugar concentrations and increases its tolerance to the high concentration in ethanol and as well as $\mathrm{Na}+$, which passively diffuses through the cell and stimulates the transport of sugars (Jones et al. 1981).

\section{Fermentation of Diss hydrolyzate}

The optimized hydrolyzate of the Diss obtained with the ratio 5\% at the temperature of $110^{\circ} \mathrm{C}$ and at $180 \mathrm{~min}$ was used as substrate for bioethanol production by $S$. cerevisiae cells at $30^{\circ} \mathrm{C}$. The results of the OD value measurements are shown in Fig. $3 \mathrm{~b}$. As can be seen, in the first $10 \mathrm{~h}$, the growth rate was little bit slower but after this OD600 (the content of yeast cells) value was increased almost linearly in the next $30 \mathrm{~h}$ of fermentation, with rate of growth approximately of $0.064 \mathrm{~h}^{-1}$ (Tab. 6).

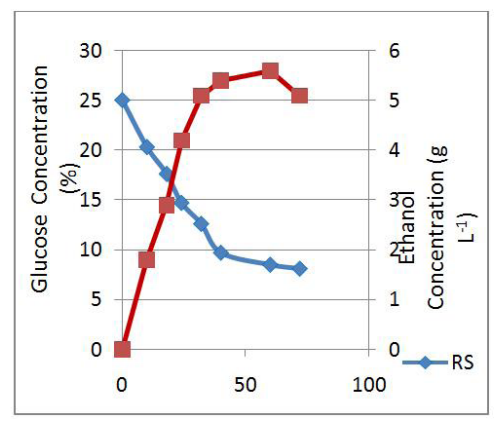

(a)

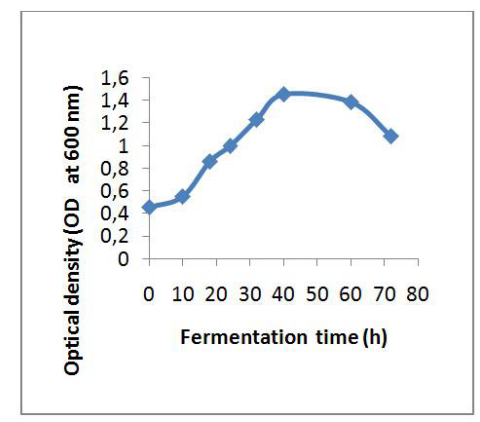

(b)

Fig. 3: Glucose concentration during ethanol production (a) and changes in optical density of S. cervisiae ATCC 9763, (b) during fermentation of Diss hydrolyzate.

Tab. 6: Values of the significant fermentation parameters obtained during the fermentation of Diss bydrolyzate by S. cerevisiae cells.

\begin{tabular}{|l|c|}
\hline \multicolumn{1}{|c|}{ Parameters } & Substrate Diss hydrolyzate \\
\hline Initial reduction sugars $\left(\mathrm{g} \cdot \mathrm{L}^{-1}\right)$ & 25 \\
\hline Final reduction sugars $\left(\mathrm{g} \cdot \mathrm{L}^{-1}\right)$ & 8.1 \\
\hline Final ethanol concentration $\left(\mathrm{g} \cdot \mathrm{L}^{-1}\right)$ & 5.6 \\
\hline Final biomass concentration $\left(\mathrm{g} \cdot \mathrm{L}^{-1}\right)$ & 1.022 \\
\hline Specific growth rate $(\mu) \mathrm{h}-1$ & 0.064 \\
\hline Biomass Yield $(\mathrm{g} \cdot \mathrm{g}-1)$ & 0.06 \\
\hline Ethanol yield per consumed sugar $\left(\mathrm{g} \cdot \mathrm{g}^{-1}\right)$ & 0.33 \\
\hline
\end{tabular}

During this period ran the exponential phase of yeast cells growth, as a consequence of the residual oxygen content in Diss hydrolyzate (Nagodawithana et al. 1974). After $40 \mathrm{~h}$ of fermentation, yeast cells content reached about 1.5 OD600 value. With further prolongation of fermentation time, OD600 value was constant and subsequently decreased. This might be due to the high concentrations of inhibitors in the hydrolyzate, to the yeast cell autolysis 
and to the low sugar content $\left(8.5 \mathrm{~g} \cdot \mathrm{L}^{-1}\right)$ that was the only available carbon source for the yeast. As shown in Fig. 3a, during the first $32 \mathrm{~h}$ of fermentation, the ethanol concentration was $5.2 \mathrm{~g} \cdot \mathrm{L}^{-1}$. With further fermentation, the ethanol concentration was slightly increased up to $5.9 \mathrm{~g} \cdot \mathrm{L}^{-1}$ for $40 \mathrm{~h}$ of incubation. These fermentation results for $32 \mathrm{~h}$ and $40 \mathrm{~h}$ corresponded to the ethanol yield of 0.419 and $0.385 \mathrm{~g}$ per $\mathrm{g}$ of reducing sugar, which were the $81.99 \%$ and $75.34 \%$ of the theoretical ethanol yield, respectively. The yield of ethanol obtained by this fermentation was lower than the theoretical concentration of ethanol. This result can be explained by the fact that a part of the sugars was consumed by the yeasts for their metabolism.

\section{CONCLUSIONS}

The yearly renewable plant employed in this study, Diss, presented carbohydrate content around 55\% having then the potential for biotechnology production. Factorial experimental design was used for the optimization of acid hydrolysis process conditions as well as to investigate interaction between acid hydrolysis process factors using STATISTICA software (V10). The effects of Ratio, temperature, and hydrolysis time on the reducing sugars yield were investigated. A second-order polynomial regression model was assumed for predicting response and the probability $\mathrm{p}$ value of 0.0002 indicated the model was highly significance. The choice of the mathematical model was confirmed by variance analysis. It was concluded that the assumed second-order polynomial models satisfactorily explained the effects of the above-mentioned variables on the RS yield. RS yield of $0.249 \mathrm{~g} \cdot \mathrm{g}^{-1}$ of dry weight was obtained when optimum conditions were ratio $5 \%$, temperature of $110^{\circ} \mathrm{C}$ and, time of $3 \mathrm{~h}$. Validation experiments verified the accuracy of the model with desirability more than $90 \%$. The predicted value was in agreement with the experimental value $\left(0.249 \mathrm{~g}_{\mathrm{g}}{ }^{-1}\right)$. From the hydrolysis studies, it was concluded that Diss shows a high potential to be converted to a valuable product, which is reducing sugar. In this work, the possibility of using Diss hydrolyzate as substrate for ethanol production without the addition of any synthetic nutrients to the media was demonstrated. Results obtained in the present study are promising in terms of bioethanol yields $\left(0.33 \mathrm{~g} \cdot \mathrm{g}^{-1} \mathrm{RS}\right)$.

\section{REFERENCES}

1. Bezerra, M.A., Santelli, R.E., Oliveira, E.P., Villar, L.S. and Escaleira, L.A., 2008: Response on face method (RSM) as an optimization tool in analytical chemistry. Talanta 76: 965-977.

2. Boutine, D.E., 2011: Evaluation de l'activité antioxydante et antibactérienne d'une plante endémique algérienne Ampelodesma mauritanica. Thèse de magistère. Université Badji Mokhtar, Annaba, Algérie. 73 pp.

3. Busti, S., Coccetti, P., Alberghina, L., Vanoni, M., 2010: Coordinated glucose coordination of growth and cell cycle in Saccharomyces cerevisiae. Sensors 10: 6195-6240.

4. Carvalho, D.M., de Queiroz, J.H., Colodette, J.L., 2016: Assessment of alkaline pretreatment for the production of bioethanol from eucalyptus, sugarcane bagasse and sugarcane straw. Industrial Crops and Products 94: 932-941.

5. Chambers, C., Exaudi-Larse, K., Price, W., 1996: Aqueous extraction of solutes from oranges: a kinetic study. Food Chemistry 57(4): 483-486. 
6. Chan, S.W., Lee, C.Y., Yap, C.E., Wan Aida, W.N., Ho, C.W., 2009: Optimization of extraction conditions for phenolic compounds from limaupurut (Citrus hystrix) peels. International Food Research Journal 16: 203-213.

7. Chenah, M., Amrani, M., 2018: Chemical and structural analysis of lignocellulosic biomass of Ampelodesmos mauritanicus (diss) and Stipa tenacissima. Wood Research 63(4): 699-712.

8. Demirbas, A., 2007: Progress and recent trends in biofuels. Progress in Energy and Combustion Science 3(1): 1-18.

9. Gigac, J., Fišerová, M., Stankovská, M., Pažitný, A., 2017: Enzymatic hydrolysis of extruded wheat straw with addition of sodium hydroxide and calcium hydroxide. Wood Research 62(6): 919-930.

10. Jones, R.P., Pamment, N., Greenfield, P.F., 1981: Alcohol fermentation by yeasts, the effect of environmental and other variables. Process Biochemistry 16(3): 42-49.

11. Khajvand, T., Chaichi, M.J., Nazari, O.L., Golchoubian, H. 2011: Application of BoxBehnken design in the optimization of catalytic behavior of a new mixed chelate of copper (II) complex in chemiluminescence reaction of luminol. Journal of Luminescence 131: 838-842.

12. Kirk, P.L., 1950: Kjeldahl method for total nitrogen. Analytical Chemistry 22 (2): 354-358.

13. Lu, M., Yuan, D., Li, Q., Ouyang, T., 2009: Application of response surface methodology to analyze the effects of soil/liquid ratio, $\mathrm{pH}$, and incubation time on the bioaccessibility of PAHs from soil in vitro method. Water Air and Soil Pollution 200: 387-397.

14. Miller, G.L., 1959: Use of dinitrosalicylic acid reagent for determination of reducing sugar. Analytical Chemistry 31: 426-428.

15. Montgomery, D.C., 2001: Design and analysis of experiments. John Wiley \& Sons, Inc., New York, 5th ed., 684pp.

16. Montgomery, D.C., 2009: Design and analysis of experiments. Wiley, New York, 7th ed., 256pp.

17. Mussatto, S.I., Roberto, I.C., 2001: Hydrolysate detoxification with activated charcoal for xylitol production by Candida guilliermondii. Biotechnology Letters 23: 1681-1684.

18. Nagodawithana, T.W., Castellano, C., Steinkraus, K.H., 1974: Effect of dissolved oxygen, temperature, initial cell count, and sugar concentration on the viability of Saccharomyces cerevisiae in rapid fermentations. Applied microbiology 28(3): 383-391.

19. Pažitný, A., Russ, A., Boháček, Š., Bottová, V., Černá, K., 2013: Utilization of energetic grass fibre for modification of recovered fibre properties. Wood Research 58(2): 181-190.

20. Pažitný, A., Russ, A., Boháček, Š., Stankovská, M., Ihnát, V., Šutý, Š., 2019a: Various lignocellulosic raw materials pretreatment processes utilizable for increasing holocellulose accessibility for hydrolytic enzymes. Part II. Effect of steam explosion temperature on beech enzymatic hydrolysis. Wood Research 64(3): 437-448.

21. Pažitný, A., Russ, A., Boháček, Š., Stankovská, M., Šutý, Š., 2019b: Various lignocellulosic raw materials pretreatment processes utilizable for increasing holocellulose accessibility for hydrolytic enzymes. Part I. Evaluation of wheat straw pretreatment processes. Wood Research 64(1): 13-24.

22. Silva, S.S., Felipe, M.G.A., Vitolo, M., 1998: Xylitol production by Candida guilliermondii FTI 20037 grown in pretreated sugar cane bagasse hydrolysate. Sustainable agro food energy industry. 1116-1119.

23. Singh, R., Shukla, A.,Tiwari, S., Srivastava, M., 2014: A review on delignification of lignocellulosic biomass for enhancement of ethanol production potential. Renewable and Sustainable Energy Reviews 32: 713-728. 
24. Stankovská, M., Fišerová, M., Gigac, J., Pažitný, A., 2018: Effect of alkaline extrusion pretreatment of wheat straw on filtrate composition and enzymatic hydrolysis. Cellulose Chemistry and Technology 52 (9-10): 815-822.

25. Tan, Q.L.P., Kieu, X.N.T., Kim, N.H.T., Hong, X.N.T., 2012: Application of response surface methodology (RSM) in condition optimization for essential oil production from Citrus latifolia. Emirates Journal of Food and Agriculture 24: 25-30.

26. Thomas, K.C., Inglewed, W.M., 1992: Production of $21 \%(\mathrm{v} / \mathrm{v})$ ethanol by fermentation of very high gravity (VHC) wheat mashes. Journal of Microbiology 10: 61-68.

27. Vargas, F., Dominguez, E., Vila, C., Rodriguez, A., Garrote, G., 2005: Agricultural residual valuation using a hydrothermal process for second generation bioethanol and oligosaccharides production. Bioresource Technology 191: 263-270.

28. Wang, D.I., Cooney, C.L., Demain, A.L., Dunnill, P., Humphrey, A., Lilly, M., 1979: Fermentation and enzyme technology. Wiley-interscience publication, New York, hardbound, $374 \mathrm{pp}$.

29. Winter, J.F., Loret, M.O., Uribelarrea, J.L., 1989: Inhibition and growth factor deficiencies in alcoholic fermentation by Saccharomyces cerevisiae. Current Microbiology 18: 247-252.

30. Wongkittipong, R., Prat, L., Damronglerd, S., Gourdon, C., 2004: Solid liquid extraction of andrographolide from plants experimental study, kinetic reaction and model. Separation and Purification Technology 4: 147-154.

\author{
Chenah May*, Amrani Moussa \\ M'hamed Bougara University \\ Faculty of Science \\ Laboratory of Soft Technology, Recovering and Sustainable Development \\ 35000 Boumerdes \\ Algeria \\ *Corresponding author: chenah-may@hotmail.fr
}

